\title{
Bioremediation of Petroleum Oil Sludge Polluted Brackish Water Ecosystem
}

\author{
Vincent C. Wokem* , Lucky O. Odokuma and Caroline N. Ariole \\ Department of Microbiology, University of Port Harcourt, P.M.B. 5323, Port Harcourt, \\ Rivers State, Nigeria \\ *Corresponding author
}

\section{Keywords}

Bioremedation, petroleum oily sludge,

Hydrocarbon utilizing bacteria (HUB), Total petroleum hydrocarbon (TPH), Polycyclic aromatic hydrocarbon (PAH)

Article Info

Accepted:

24 August 2019

Available Online:

10 September 2019

\section{A B S T R A C T}

Petroleum oil sludge resulting from crude oil storage, illegal crude oil refining and bunkering activities constitutes environmental hazards and pollution in the crude oil producing communities in the Niger Delta region of Nigeria. Biostimulation with N.P.K. fertilizer option C, bioargumentation with indigenous hydrocarbon utilizing bacteria (HUB) option B, combination of biostimulation and bioaugmentation as option $\mathrm{A}$ and option $\mathrm{D}$ was without any bioremediation treatment were employed in the bioremediation of brackish water artificially polluted with petroleum oil sludge. Brackish water sample was obtained from Elechi Creek, Port Harcourt Rivers State. Petroleum oil sludge sample was obtained from Crude Oil Processing Plant in Obegi community, Rivers State. Bioremediation was monitored for 56 days using the percentage ratio of total petroleum hydrocarbon (TPH) losses for each period to TPH loss at day 0 . The result of physicochemical analysis of the petroleum sludge showed that aliphatic hydrocarbon (n-alkanes) ranged from $\mathrm{C}_{13}-\mathrm{C}_{35}$, with concentrations ranging from 26.12-7,713.62ppmwith TPH of 89,509.9ppm. The polycyclic aromatic hydrocarbon $(\mathrm{PAH})$ range was $0.03-5.36 \mathrm{ppm}$ with total concentration of $24.21 \mathrm{ppm}$. Heavy metal analysis showed; iron $(49.42 \mathrm{mg} / \mathrm{kg})$, Zinc $(3.79 \mathrm{mg} / \mathrm{kg})$, Nickel $(4.53 \mathrm{mg} / \mathrm{kg})$ and manganese $(6.90$ $\mathrm{mg} / \mathrm{kg}$ ). The average total heterotrophic bacterial (THB) and (HUB) counts for petroleum sludge were; $2.5 \times 10^{5} \mathrm{cfu} / \mathrm{g}$ and $2.0 \times 10^{5} \mathrm{cfu} / \mathrm{g}$ and for the brackish water sample were $1.39 \times 106 \mathrm{cfu} / \mathrm{ml}$ and $1.1 \times 10^{4} \mathrm{cfu} / \mathrm{ml}$ respectively. Statistical analysis (ANOVA) showed that the THB and HUB counts were significantly different at 5 percent levels $(\mathrm{P}<0.05)$ in the different treatment options during the bioremediation period. Changes in physico-chemical parameters showed that $\mathrm{pH}$, alkalinity, conductivity, chemical oxygen demand, nitrate and phosphate were significantly different $(\mathrm{P}<0.05)$ while there were no significant differences $(\mathrm{P}>0.05)$ in the following parameter; salinity biochemical oxygen demand and total hydrocarbon continent.Using least significant difference (LSD), treatment option D and the control option E were different from treatments A, B and C. The phylogenetic analysis identification of the HUB isolates implicated in the degradation process revealed a closely related ness to the following organisms, Lysinibacillus sphaericus, Klebsiella pneumonia and Alcaligenes faecalis of different strains. The bacterial sequences submitted to Genbank were assigned Accession Number KX817218-KXV7225. The percentage losses in TPH from Gas Chromatography (GC) results showed the following; option A (91.8\%), option B (92.5\%), C (95\%) D $(57.8 \%)$ and option E control (39.5\%) respectively. The results suggest that the application of biostimulation with N.P.K fertilizer, bioaugmentation with indigenous HUB or a combination of both will enhance the bioremediation of petroleum sludge polluted brackish water system in the Niger Delta of Nigeria. 


\section{Introduction}

Petroleum sludge is made up of hydrocarbons, solids and other impurities and the remaining being water. Huge amount of petroleum sludge is formed during oil processing in refineries and oil processing as well as during illegal oil refining and bunkering in the creeks of oil producing communities. High demand for petroleum products has led to generation of large amount of oily wastes (Bhttacharyya and shekalar 2003). The petroleum oily sludge is attributed to two major factors; sedimentation of inorganic residues in the crude oil and the precipitation of paraffin wax, since wax precipitates are sparingly soluble in crude oil (Milne, 1998). Petroleum is capable to penetrate into ground and pollute ground water, surface water and the terrestrial environment if not properly treated and managed (Manning and Thompson, 1995). The components of petroleum sludge are toxic, mutagenic and carcinogenic and may persist in the environment for long period; posing environmental problem both to the aquatic and terrestrial ecosystems (Wu et al., 2008; Ayotamuno, et al., 2011, Balanchandran et al., 2012).

When hydrocarbon pollutants get into the aquatic systems, they may be biodegraded by indigenous micoorganisms (Okpokwasili and Odukuma, 1990), though they may pose toxicity problems to indigenous microflora. Hydrocarbon contamination generally can cause damages to the aquatic vegetation (Krebs and Tanner, 1981). The young fish and aquatic invertebrates are the most threatened organisms in the aquatic environment (Calfee et al., 1999). Hydrocarbon toxicity due to the presence of PAHs has greater environmental and public health implication as it can pass on to human population. These effects will eventually lead to socio-economic impact of decline in food production, youth restiveness and community unrest.
The use of conventional techniques (mechanical removal, sediment relocation and application of chemical dispersants) are generally expensive and exposes personnel to health hazards. The ability of microorganisms to degrade hydrocarbon pollutants in the environment has been employed in the remediation of hydrocarbon contaminated sites. Several studies have reported on the abilities of microorganisms (bacteria, fungi and algae) to degrade petroleum hydrocarbons (Riser-Roberts 1992; Dean-Ross et al., 2002; Bundy et al., 2004; Chikere et al., 2009; Wang et al., 2011; Malik and Ahmed, 2012; Ahirwar and Dehariya, 2013; Macaulay, 2015). Bioremediation is the use of biological process and agents especially microbial, to degrade the environmental contaminants into less toxic forms (Vidali, 2010). Biodegradation transforms and mineralize organic compounds, though complete mineralization is often not realized. Only when environmental conditions permit microbial growth activity would the applicationbe effective. Thus, manipulation of environmental parameters to achieve fast growth rate and optimal activities is a necessity (Mukred et al., 2008). Biostimulation and bioaugmentation are methods of bioremediation geared towards enhancing the process. Biostimulation is the injection of amendments (nutrients) into contaminated soil or water to stimulate indigenous microbial population already present to enhance the pollutant degradation (Obire and Akinde, 2004). Amendment may include oxygen, nutrient (organic or inorganic fertilizer), electron acceptors (Tyagi et al., 2011). Stimulation of the activity of indigenous microflora to remediate the target pollutant can also be accelerated by adjustment of physical process such as $\mathrm{pH}$ and moisture (Vidali, 2001). Bioaugmentation involves the addition of exogenous or indigenous bacterial cultures to the contaminated matrix to decontaminate it. It is 
more commonly and successfully carried out by addition of large population of selected microorganisms grown in the laboratory removed from the contaminated sites (Vidali, 2001). Application of genetically engineered bacteria has been used for bioremediation trials. Genes could be introduced into native species using other genetic vectors such as plasmids (Crisafi et al., 2016) A combination of both biostimulation and bioaugmentation has also been employed in bioremediation process (Odokuma and Dickson, 2003;Mukred et al., 2008). This present study compared the biostimulation with N.P.K fertilizer, bioaugmentation with indigenous HUB isolates, combination of biostimuation and bioaugmentation as well as intrinsic bioremediation (natural attenuation) techniques in the bioremediation of petroleum sludge polluted brackish water ecosystem.

\section{Materials and Methods}

\section{Sample Collection}

Brackish water sample was collected from Elechi creek located in Port Harcourt Rivers stated behind Nigeria Agip Oil Company (NAOC) and Rivers State University, Nkpolu, Port Harcourt. The area lies on latitude $4^{\circ}$ 47'37.6 "N" and longitude 6 58'20.6 "E". Sample bottle was rinsed trice with the river water before collection (ASTM, 1999). Water sample was collected by gradually lowering the bottle into the sub-surface $(10-20 \mathrm{~cm}$ of the river in direct sunlight. The bottle was opened and allowed to be filled and closed below the water. Water was collected into 4 liter plastic bottle and transported in ice-pack to the laboratory. Water sample was refrigerated at $4^{\circ} \mathrm{C}$ and covered. The petroleum oily sludge was collected from the crude oil processing plant belonging to Total Exploration and Production, (Total E \& P) Nigeria limited, located at Obegi community, Rives state. Petroleum oily sludge was collected at the base of crude oil storage tank during cleaning exercise with soil auger into sterile glass jar and covered. It was transported in ice pack to the laboratory and stored in refrigerator at $4^{\circ} \mathrm{c}$.

\section{Reagents}

All regents employed in the study were of analytical grade and were obtained from Sigma-Aldrich chemical company, USA, and BDH chemical Ltd, Poole, England. All microbiological media used were products of Oxoidand Difco Laboratories England and Sigma-Aldrich, USA. Filter paper (whatman No.1) was obtained from WER Bauston Ltd, London. DNA extraction Kit was obtained from Inqaba Biotechnical Industries, South Africa. Bonny light crude oil used for HUB screening was obtained from Port Harcourt Refinery Company, Eleme, Rivers State, Nigeria. The NPK (Nitrogen, Phosphorus and Potassium) 20:10:10 NPK fertilizer used in this study was obtained from Indorama Eleme Petrochemicals Ltd, Port Harcourt, Nigeria.

\section{Experimental Set-Up}

The bioremediation experimental design consisted of five 2 liters Erlenmeyer flasks. The flasks were labeled A, B, C, D and E.To each flask $300 \mathrm{ml}$ of brackish water and $100 \mathrm{~g}$ of petroleum sludge were added.

The different treatment options were constituted as follows: (Table 1)

Option A: Addition of $5 \mathrm{ml}$ of $10 \%$ wt $/ \mathrm{v}$ NPK fertilizer and $5 \mathrm{ml}$ of bacteria broth culture from the water and sludge samples. The isolates were sub-cultured into nutrient broth as mix culture and allowed to stand for $6 \mathrm{~h}$ before inoculating into the test set up aseptically by use of sterile syringes.

Option B: Addition of $5 \mathrm{ml}$ of bacterial broth culture. 
Option C: Addition of $5 \mathrm{ml} 10 \%{ }^{\mathrm{wt}} / \mathrm{v}$ NPK fertilizer.

Option D: No addition of fertilizer and bacterial broth culture.

Option E: Addition of $5 \mathrm{~g}$ sodium azide biocide to eliminate microorganism). This served as control.

Each set up was plugged with cotton wool and allowed to stand at room temperature $\left(28 \pm 2^{0} \mathrm{C}\right)$ for 56 days. Repeated sampling procedures were carried out for microbiological and physico-chemical analysis at day 0 and subsequently at day 14 , 28,42 and 56 respectively.

\section{Enumeration of Microbial Population}

The total heterotrophic bacteria (THB) counts of water, petroleum sludge samples and bioremediation tests set up were performed in triplicates on nutrient agar (NA) oxoid using spread plate method (APHA, 1998). Plates were properly labeled and incubated at $37^{\circ} \mathrm{C}$ for $24 \mathrm{~h}$.

The HUB counts of water, petroleum sludge and bioremediation tests samples were carried out in triplicates on Mineral Salt Agar (MSA) of Mills et al., (1978) as modified by Okpokwasili and Odokuma (1990). Vapour phase transfer method (Amanchukwu et al., 1998) was employed by placing sterile Whatman No 1 filter papers saturated with filtered-Bonny light crude oil into the inside lids of each petri dish kept in an inverted position, incubated at $30^{\circ} \mathrm{C}$ for 3-7 days. The plates were examined for colony formation and enumeration. Identification and characterization of culturable HUB bacterial isolates were based on Gramsreaction tests their morphological features and series of biochemical tests. When compared with the characteristics of known using the determination schemes of Chesbrough (2006) and Holt et al., (1994).

\section{Molecular Identification of the HUB Isolates}

\section{DNA Extraction}

DNA extraction was carried out by using a ZR fungal/bacterial DNA miniprep-extraction kit obtained from Inquaba, South Africa. Heavy growth of the pure isolates subcultured on MacConkey's agar plates were suspended in 200 microlitre of isotonic into a ZR bashing bead lysis tubes, $750^{\mu}$ of lysis solution was added to the tubes. The tubes were held in position in a bead beater fitted with a zml holder assembly and processed at maximum speed for 5 minutes. The ZR bashing-bead lysis tubes were centrifuged at $10,000 x$ g for 1 minute. Four hundred (400) $\mu 1$ of the supernatant were transferred aseptically with micropipette into zymo-spin IV spin filter (orange top) in a collection tube and centrifuged at $7000 \mathrm{xg}$ for a minute, then $1200 \mu$ l of DNA binding buffer was added to each filtrate in the collection tubes bringing the final volume to $1600 \mu \mathrm{l}$. $800 \mu \mathrm{l}$ was afterwards twirled into zymo-spin IIC column in a collection tube and centrifuged at 10,000 $\mathrm{xg}$ for a minute, the flow through were discarded. The remaining volumes were wirled into the same zymo-spin and spun at $10,000 \mathrm{xg}$ for a minute. $200 \mu \mathrm{l}$ of the DNA prewash buffer were added to the zymo-spin IIC in a fresh collection tubes and spun at $10,000 \times \mathrm{xg}$ for a minute followed by the addition of 500 $\mu 1$ of bacterial DNA, buffered and centrifuged at $10,000 \mathrm{xg}$ for a minute. The zymo-spin IIC column were transferred to clean fresh $1.5 \mu \mathrm{l}$ centrifuge tubes, $100 \mu \mathrm{l}$ of DNA elution buffer were added to the column matrix and centrifuged at $10,000 \times \mathrm{xg}$ for 30seconds to elute the DNA. The ultrapure DNA of each isolate properly labeled were then stored at $-20^{\circ} \mathrm{C}$ for use. DENVILLE 
260OD Brushless micro-centrifuge was used for the centrifugation process. After extraction, the DNA samples were quantified using NANODROP (ND1000).

\section{Agarose gel electrophoresis}

The extracted genomic DNA were resolved on a $1 \%$ agarose gel at $120 \mathrm{v}$ for 15 minutes and visualized on a UV transilluminator alongside with a $1 \mathrm{~kb}$ ladder for size determination of the isolates DNA sizes.

\section{S rRNA amplification}

The 16s RNA region of the rRNA genes of the isolates were amplified using the $27 \mathrm{~F}$ and 1492R primers on a PCR System 9700 Applied Biosystem thermal cycler at a final volume of $25 \mu \mathrm{l}$ for 40 cycles. The PCR mix included: the $\mathrm{x} 2$ dream tag master mix supplied by Inqaba, South Africa (tag polymerase DNTPs, magnesium chloride $\left(\mathrm{MgCl}_{2}\right)$, the primers at a concentration of $0.4 \mathrm{M}$ and the extracted DNA as template. The PCR condition were as follows: initial denaturation, $95^{\circ} \mathrm{C}$ for 4 mins, denaturation, $95^{\circ} \mathrm{C}$ for 30 seconds; annealing $52^{\circ} \mathrm{C}$ for 30 seconds; extension $72^{0} \mathrm{C}$ for 1 minute for 40 cycles and final extension $72^{\circ} \mathrm{C}$ for 3 mins. Than the products were resolved on a $1 \%$ agarose gel at $120 \mathrm{~V}$ for 15 mintes and visualized on a UV transilluminator (Ce born et al., 2008).

\section{I6SrRNA sequencing}

The amplified 16s products were sequenced on a 3500 genetic analyzer using the Bigdye termination technique by Inqaba, South Africa.

\section{Phylogenetic analysis}

The sequence were edited using the bioinformatics algorithm Bio edit, similar sequences were downloaded from the National Biotechnology Information Centre (NBIC) data base using BlastN. These sequences were aligned using clusta $1 \mathrm{X}$. The evolutionary history of the isolates and relatedness were inferred following protocols described in Saitou and Nei (1987); Felsenstein (1985) and Thompson et al., (1994). The result of the bacteria sequences was submitted to GenBank for determination of accession numbers.

Physicochemical parameters of brackish water, petroleum sludge and bioremediation monitoring samples analysed included; $\mathrm{pH}$, alkalinity, salinity, biological oxygen demand (BOD), chemical oxygen demand (COD), nitrate, phosphate, total hydrocarbon content (THC), sulphate, total petroleum hydrocarbon (TPH) and polycyclic aromatic hydrocarbons (PAHs).

They were determined using methods adopted from Stewart et al., (1974). Determination of THC was according to ASTM (1999) method D3921. The use of gas chromatographic Flame Ionization Detector (FID) were employed for TPH and PAH. The methods were based on (ASTM-D7678, 1999 and ASTM-D8270 (1999) respectively.

\section{Heavy Metal Analysis}

The petroleum sludge and condensate samples were analysed for the presence of iron, zinc, copper, vanadium, nickel, lead and manganese using G.B.C. Avanta Atomic Absorption Spectrophotometer (AAS) with detection limit of $0.05 \mathrm{mg} / \mathrm{kg}$. The process involves flame optimization. Prior to flame optimization, the water trap on the instrument was filled with distilled water as blank and the water level in the discharge container was reduced. It was ensured that the tip of the hose stays above the water level in the discharge container during running the AAS, 
as well as ensuring that the burner head was clean, free from debris and confirming that aspirator was ducking properly.

Prior to analysis, the AAS was calibrated with standards of known concentrations to obtain curve for the individual metal. Concentration of each of the heavy metal was ascertained from the data generated by the AAS and expressed in ppm. At the end of the run, the displayed result was printed out. All gas pressures, used in the analysis were set to 70 psi.

Determination of percentage losses in TPH in the various bioremediation treatment options were carried out by obtaining the difference in TPH values of GC results of the day 0 and that of TPH GC result of day 56. Calculation was percentage of ratio of TPH for day 0,14 , 2, 42 and 56 to TPH at day 0 .

$\frac{(T P H \text { at day } 0-T P H \text { at day } 56}{\text { TPH at day } 0} \times 100 \%$

\section{Statistical Analysis}

Analysis of variance (ANOVA) method and the least significant difference (LSD) test of 95\% levels of confidence were employed with Statistical Package for Social Science (SPSS) to determine significant statistical differences in microbial counts and changes in physicochemical parameters between the different treatment options.

\section{Results and Discussion}

The physicochemical characteristics of the brackish water and petroleum sludge used in the study are presented in Tables 2 and 3 respectively. The brackish water sample had high salinity of $12,280.8 \mathrm{mg} / \mathrm{l}$ and conductivity of $1,407^{\mu_{\mathrm{s}}} / \mathrm{cm}$. The high salinity and conductivity contents of the brackish water sample could be as a result of inflow of sea water and discharge of domestic and industrial waste water into the water body (Nester et al., 2001). The value of THC $(0.85 \mathrm{mg} / 10$ of the water body showed that there was no previous hydrocarbon contamination of the water body. The permissible limit of THC in natural aquatic systems is $10 \mathrm{mg} / \mathrm{l}$ (DPR, 2002). The high values of $\mathrm{BOD} \quad(448 \mathrm{mg} / \mathrm{l}), \quad \mathrm{COD}$ $(1,600.0 \mathrm{mg} / \mathrm{l}), \quad$ THC $\quad(915.0 \mathrm{mg} / \mathrm{l}), \quad$ TPH $(89,509.9 \mathrm{mg} / \mathrm{l})$ and PAHs $(24.21 \mathrm{mg} / \mathrm{l})$ of the petroleum sludge implies that it constitutes potential environmental hazard. The results of characterization of aliphatic hydrocarbon (nalkanes) and PAHs in the petroleum sludge reveals that the n-alkanes ranged from carbon length of $\mathrm{C}_{13}$ to $\mathrm{C}_{37}$ with concentrations ranging from 26.7-7,713.63ppm, $\mathrm{C}_{17}$ (Heptadecane) was the most significant nalkane with highest concentration (7,713.63ppm) while $\mathrm{C}_{37}$ (heptatriacontane) had the least concentration (26.12ppm) Table 5. The PAHs concentration indicated that Benzo (b) fluoranthene had the highest concentration $(5.36 \mathrm{ppm})$ while anthracene was least $(0.03 \mathrm{ppm})$. Naphthalene, benzo (a) anthracene, chrysene, benzo (ghi) perylene and indeno (1,2,3-cd) pyrene were not detected (Table 6). The presence of these PAHs in the petroleum sludge is an indicator of high pollutant. The AAS concentration results of heavy metals in the petroleum sludge revealed high iron $(\mathrm{Fe})$ content of 49.42ppm compared with other heavy metals investigated ( $\mathrm{Zn}, \mathrm{Cu}, \mathrm{V}, \mathrm{Ni}, \mathrm{Pb}$ and $\mathrm{Mn}$ ) which were relatively lower (Table 4). Many metals are essential for growth of microorganisms in lower concentrations, yet are toxic in higher concentrations. Many microorganisms have the ability to selectively accumulate metals by the process of biosorption which involves the building or adsorption of heavy metals to living or dead cells (Vijayadeep and Sastry, 2014). The concentrations of the heavy metals analysed in the petroleum sludge in this study may not 
have affected the microbial growth in the overall biodegradation process.

The proportion of microbial population capable of hydrocarbon degradation in an aquatic habitat is influenced by a number of factors, one of which is the environmental conditions (Odokuma and Okpokwasili, 1993a; Odokuma and Okpokwasili, 1993b; Odokuma and Okpokwasili, 1997; Mona et al., 2015). The $\mathrm{pH}$ of the brackish water (7.27) and petroleum sludge (7.32) which showed $\mathrm{pH}$ near neutrality were ideal for biological functions (Nester et al., 2001). Changes in $\mathrm{pH}$ during the bioremediation period showed $\mathrm{pH}$ near neutrality. This favours most heterotrophic and HUB activities (Atlas, 1984). The $\mathrm{pH}$ changes during the monitoring period may be due to reduction in acidic compounds production and/or protons secretion. Generally, the $\mathrm{pH}$ of the various treatment options is a function of the chemical composition of the pollutant, water and microbial activities (Odokuma and Ibe, 2003; Delyan et al., 1990; Mayo and Noike, 1996).

The bacterial counts of the brackish water and petroleum sludge are presented in Table 7 . It showed that the brackish water had higher THB count $\left(1.39 \times 10^{6} \mathrm{cfu} / \mathrm{ml}\right)$ than the sludge $\left(2.5 \times 10^{5} \mathrm{cfu} / \mathrm{g}\right)$ while the sludge had higher HUB count $\left(2.0 \times 10^{5} \mathrm{cfu} / \mathrm{g}\right)$ than the brackish water $\left(1.1 \times 10^{4} \mathrm{cfu} / \mathrm{ml}\right)$. The bacterial growth profile (THB and HUB) during the period are illustrated in Figures 1-2. They followed the same trend, except in the control option E, where an extremely low THB and HUB counts were observed as a result of the addition of biocide which eliminated microorganisms in the test systems (Figs. 12).

Statistical analysis results of growth profile of THB and HUB showed that there was significant difference in the treatment options at $5 \%$ confidence levels $(\mathrm{P}<0.05)$. This also indicated that the pollutant (petroleum sludge) was utilizable source of carbon and energy for the HUB cells (Milic et al., 2009; Hara et al., 2013; Singh and Chandra, 2014). The decline in bacterial counts from day 42 to 56 may be due to nutrient exhaustion with possible accumulation of toxic metabolites which gave rise to stationary and death phases (Nester et al., 2001). The relative few or no growth observed in the control option E, was due to the application of biocide (Odokuma and Akubuenyi, 2008). This led to low percentage loss in TPH (39.5\%) Table 8. The observed \% loss in TPH in the control option is attributable to environmental factors; natural attenuation process (auto-oxidation, evaporation, volatilization, emulsification, dispersion and sedimentation) other than biodegradation since microorganisms were eliminated.

Changes in physicochemical parameters during the period of bioremediation are illustrated in Figures 3-12. Statistical analysis (ANOVA) showed that there were significant differences at $5 \%$ level $(<0.05)$ for $\mathrm{pH}$, alkalinity, conductivity, COD, nitrate and phosphate, sulphate whereas there were no significant differences $(\mathrm{P}>0.05)$ in salinity, $\mathrm{BOD}$ and THC respectively. Least significant difference (LSD) analysis showed that treatments $\mathrm{D}$ and $\mathrm{E}$ were different from treatment $\mathrm{A}, \mathrm{B}$ and $\mathrm{C}$ for THC and TPH.

Decreases in BOD in the various tests set up suggest that the amount of degradable organic materials were being degraded by the microorganisms. They showed the same trend of decrease from Day 0 to day 56 (Fig. 7). BOD represents the amount of oxygen required for microbial decomposition of organic matter in waste water sample, it is roughly proportional to the amount of degradable organic matter present in the water sample (Nester et al., 2001). 
Table.1 Bioremediation treatment options

\begin{tabular}{|c|c|c|c|c|}
\hline \multicolumn{5}{|c|}{ Options } \\
\hline $\mathbf{A}$ & $\mathrm{B}$ & $\mathrm{C}$ & $\mathrm{D}$ & $\mathrm{E}$ \\
\hline $\mathbf{B W}+\mathrm{SL}+\mathbf{B T}+\mathbf{F T}$ & $\mathrm{BW}+\mathrm{SL}+\mathrm{BT}$ & $\mathrm{BW}+\mathrm{SL}+\mathrm{FT}$ & $\mathrm{BW}+\mathrm{SL}+\mathrm{FT}$ & $\mathrm{BW}+\mathrm{SL}+\mathrm{SA}$ \\
\hline
\end{tabular}

Key: BW = Brackish water, $\mathrm{SL}=$ Sludge, $\mathrm{BI}=$ Bacterial Innoculum, FT $=$ Fertilizer, $\mathrm{SA}=$ Sodium azide

Table.2 Physicochemical characteristics of brackish water samples

\begin{tabular}{|l|l|}
\hline Parameters & Values \\
\hline pH & $\mathbf{7 . 2 7}$ \\
\hline Salinity $(\mathbf{m g} / \mathbf{l})$ & $\mathbf{1 2 , 2 8 0 . 8}$ \\
\hline Conductivity $(\boldsymbol{\mu S} / \mathbf{c m})$ & $\mathbf{1 4 0 7}$ \\
\hline Alkalinity & 32 \\
\hline COD $(\mathbf{m g} / \mathbf{l})$ & $\mathbf{4 6}$ \\
\hline BOD $(\mathbf{m g} / \mathbf{l})$ & $\mathbf{7 . 0 4}$ \\
\hline Phosphate $(\mathbf{m g} / \mathbf{l})$ & Nil \\
\hline Nitrate $(\mathbf{m g} / \mathbf{l}$ & $\mathbf{0 . 8 8}$ \\
\hline Sulphate $(\mathbf{m g} / \mathbf{l})$ & $\mathbf{0 . 6 9}$ \\
\hline THC $(\mathbf{m g} / \mathbf{l})$ & $\mathbf{0 . 8 5}$ \\
\hline
\end{tabular}

Table.3 Physicochemical characteristics of petroleum sludge sample used in the study

\begin{tabular}{|c|c|}
\hline Parameters & Values \\
\hline pH & 7.32 \\
\hline Conductivity ( $\mu \mathrm{s} / \mathrm{cm})$ & $5,230.0$ \\
\hline Salinity (mg/l) & $3,249.0$ \\
\hline Alkalinity & $1,900.0$ \\
\hline BOD (mg/l) & 448 \\
\hline COD (mg/l) & $1,600.0$ \\
\hline Nitrate $(\mathrm{mg} / \mathrm{l})$ & 10.59 \\
\hline Phosphate (mg/l) & 0.98 \\
\hline Sulphate $(\mathrm{mg} / \mathrm{l})$ & 1858 \\
\hline Total hydrocarbon content (THC) (mg/l) & 915.0 \\
\hline Total petroleum hydrocarbon (TPH) (mg/l) & $89,509.9$ \\
\hline Polyaromatic hydrocarbons (PAHs) (mg/l) & 24.21 \\
\hline
\end{tabular}

Table.4 Heavy metal content in petroleum sludge sample used in the study

\begin{tabular}{|l|l|}
\hline Parameters & Values $(\mathrm{mg} / \mathrm{kg})$ \\
\hline Iron & 49.42 \\
\hline Zinc & $\mathbf{3 . 7 9}$ \\
\hline Copper & $\mathbf{3 . 3 2}$ \\
\hline Vanadium & $\mathbf{0 . 9 1}$ \\
\hline Nickel & $\mathbf{4 . 5 3}$ \\
\hline Lead & $\mathbf{2 . 5 9}$ \\
\hline Manganese & $\mathbf{6 . 9 0}$ \\
\hline
\end{tabular}


Table.5 Characterization of aliphatic hydrocarbons (n-alkanes) of the petroleum sludge sample used in the study

\begin{tabular}{|c|c|c|c|}
\hline $\mathbf{S} / \mathbf{N}$ & $\begin{array}{l}\text { Number of } \\
\text { carbon atoms }\end{array}$ & Name & Conc. (ppm) \\
\hline 1. & $\mathrm{C} 8$ & Octane & ND \\
\hline 2. & C9 & Nonane & ND \\
\hline 3. & C10 & Undecane & ND \\
\hline 4. & C11 & Decane & ND \\
\hline 5. & $\mathrm{C} 12$ & Dodecane & ND \\
\hline 6. & $\mathrm{C} 13$ & Tridecane & 259.07 \\
\hline 7. & C14 & Tetradecane & ND \\
\hline 8. & $\mathrm{C} 15$ & Pentadecane & 3841.17 \\
\hline 9. & $\mathrm{C} 16$ & Hexadecane & 1807.55 \\
\hline 10. & $\mathrm{C} 17+$ & Heptadecane & 4671.54 \\
\hline 11. & $\mathrm{C} 17$ & Heptadecane & 7713.62 \\
\hline 12. & $\mathrm{C} 18$ & Octadecane & 4292.26 \\
\hline 13. & C18+ & Octadecane & 6474.51 \\
\hline 14. & C19 & Nonadecane & 4125.91 \\
\hline 15. & $\mathrm{C} 20$ & Icosane & 3948.02 \\
\hline 16. & $\mathrm{C} 21$ & Hericosane & 5076.97 \\
\hline 17. & $\mathrm{C} 22$ & Decosane & 3266.03 \\
\hline 18. & $\mathrm{C} 23$ & Tripcosane & 4245.44 \\
\hline 19. & $\mathrm{C} 24$ & Tetracosane & 4256.37 \\
\hline 20. & $\mathrm{C} 25$ & Pentacosane & 5470.60 \\
\hline 21. & $\mathrm{C} 26$ & Hexacosane & 3288.36 \\
\hline 22. & $\mathrm{C} 27$ & Heptacosane & 4444.23 \\
\hline 23. & $\mathrm{C} 28$ & Octacosane & 3648.16 \\
\hline 24. & $\mathrm{C} 29$ & Nonacosane & 3015.70 \\
\hline 25. & $\mathrm{C} 30$ & Triacontane & 4891.31 \\
\hline 26. & $\mathrm{C} 31$ & Hentriacontane & 2258.78 \\
\hline 27. & $\mathrm{C} 32$ & Dotriacontane & 498.90 \\
\hline 28. & $\mathrm{C} 33$ & Tritriacontane & 1706.33 \\
\hline 29. & C34 & Tetratriacontane & 1185.64 \\
\hline 30. & C35 & Pentatricacontane & 196.66 \\
\hline 31. & C36 & Hexatricacontane & ND \\
\hline 32. & C37 & Heptatriacontane & 26.12 \\
\hline 33. & C38 & Octatriacontane & ND \\
\hline 34. & C39 & Nonatriacontane & ND \\
\hline 35. & $\mathrm{C} 40$ & Tetracontane & ND \\
\hline & & TOTAL & $89,509.9$ \\
\hline
\end{tabular}


Table.6 Characterization of Polycyclic aromatic hydrocarbons (PAHs) in petroleum sludge sample used in the study

\begin{tabular}{|l|l|c|}
\hline S/N & Name of Compound & Conc. (ppm) \\
\hline $\mathbf{1}$ & Naphthalene & ND \\
\hline $\mathbf{2}$ & Acenaphthylene & 0.29 \\
\hline $\mathbf{3}$ & Acenapthene & 1.57 \\
\hline $\mathbf{4}$ & Fluorene & 2.84 \\
\hline $\mathbf{5}$ & Phenanthrene & 5.12 \\
\hline $\mathbf{6}$ & Anthracene & 0.03 \\
\hline $\mathbf{7}$ & Fluoranthene & 2.14 \\
\hline $\mathbf{8}$ & Pyrene & 0.19 \\
\hline $\mathbf{9}$ & Benzo (a) anthracene & ND \\
\hline $\mathbf{1 0}$ & Chrysene & ND \\
\hline $\mathbf{1 1}$ & Benzo (b) fluoranthene & 5.36 \\
\hline $\mathbf{1 2}$ & Benzo (k) fluoranthene & 2.55 \\
\hline $\mathbf{1 3}$ & Benzo (a) pyrene & 4.12 \\
\hline $\mathbf{1 4}$ & Benzo (ghi) perylene & ND \\
\hline $\mathbf{1 5}$ & Indeno (1,2,3-cd) pyrene & ND \\
\hline & & $\mathbf{2 4 . 2 1}$ \\
\hline
\end{tabular}

ND $=$ Not Detected

Table.7 Bacterial Counts of Water and Petroleum sludge samples

\begin{tabular}{|l|c|c|c|}
\hline S/NO. & Type of Count & Brackish Water $(\mathbf{c f u} / \mathbf{m l})$ & Petroleum Sludge $(\mathbf{c f u} / \mathbf{g})$ \\
\hline $\mathbf{1}$ & THB & $1.39 \times 10^{6}$ & $2.5 \times 10^{5}$ \\
\hline $\mathbf{2}$ & HUB & $1.1 \times 10^{4}$ & $2.0 \times 10^{5}$ \\
\hline
\end{tabular}

Table.8 Percentage losses in TPH of various bioremediation options after 56 days in petroleum polluted brackish water

\begin{tabular}{|c|c|}
\hline Option & Percentage Loss (\%) \\
\hline A & 91.8 \\
\hline B & 92.5 \\
\hline C & 95.1 \\
\hline D & 57.8 \\
\hline E & 39.5 \\
\hline
\end{tabular}

Table.9 Identified Isolates with the GenBan Accession Numbers

\begin{tabular}{|l|l|l|}
\hline S/N & Name of Organism & Accession Number \\
\hline $\mathbf{1}$ & Klebsiella pneumoniae strain B21 & SUB1917764B1 KX817218 \\
\hline $\mathbf{2}$ & Klebsiella pneumoniae strain ICB-C183 & SUB1917764B2 KX817219 \\
\hline $\mathbf{3}$ & Klebsiellaoxytoca strain BCNA1 & SUB1917764B3 KX817220 \\
\hline $\mathbf{4}$ & Klebsiellaoxytoca strain BC4 & SUB1917764B4 KX817221 \\
\hline $\mathbf{5}$ & Alcaligenesfaecalis strain IOU PMR & SUB1917764B5 KX817222 \\
\hline $\mathbf{6}$ & Alcaligenesfaecalis strain AQ-1 & SUB1917764B6 KX817223 \\
\hline $\mathbf{7}$ & Klebsiella pneumoniae strain ICB -C26 & SUB1917764 B7 KX817224 \\
\hline $\mathbf{8}$ & Klebsiella pneumoniae strain B21 & SUB1917764 B8 KX817225 \\
\hline
\end{tabular}


Fig.1 Growth Profile of THB in Sludge Polluted brackish water sample during the monitoring of various bioremediation options

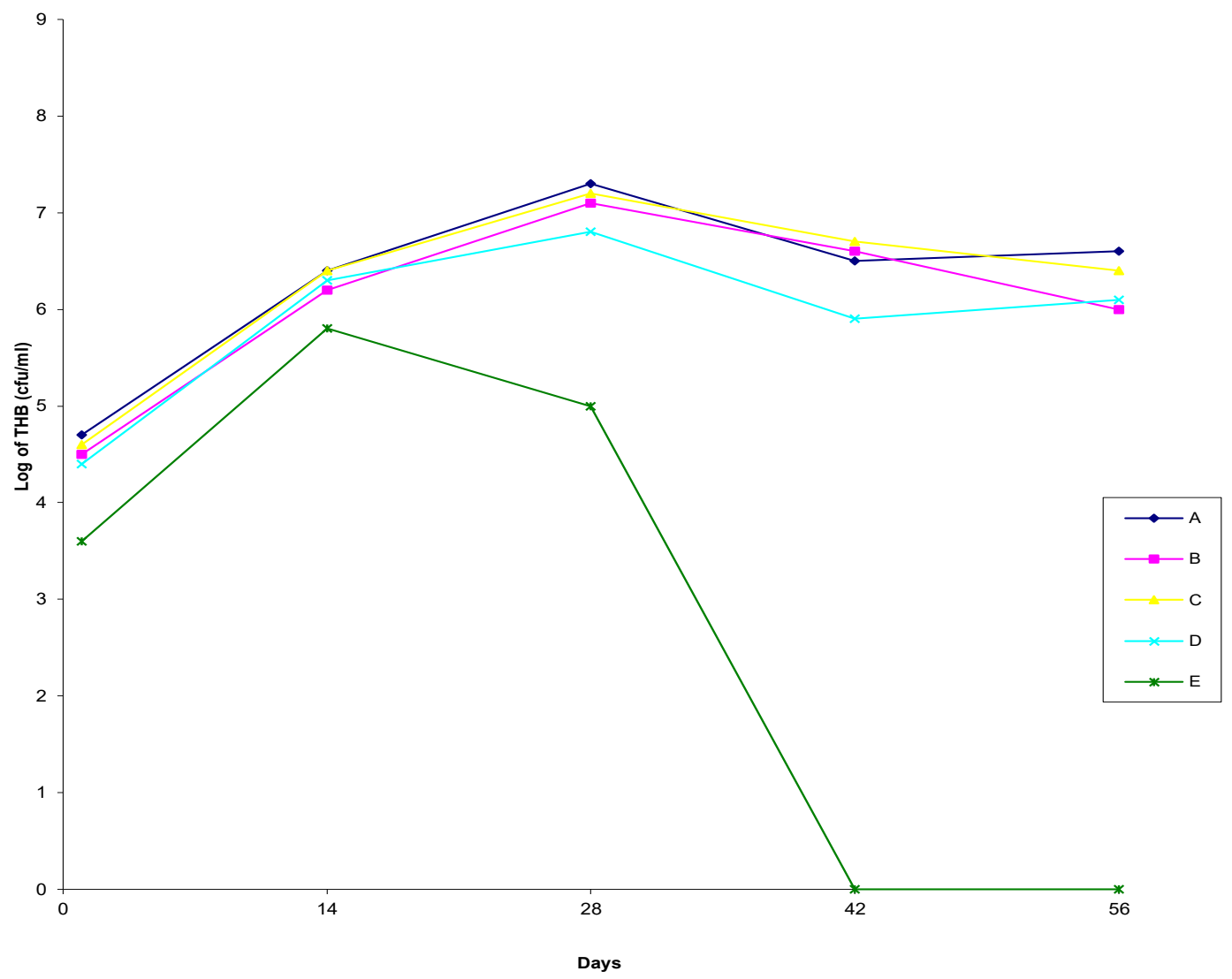

KEY

A $\quad-\quad$ APPLICATION OF BACTERIA AND FERTILIZER

$\mathrm{B} \quad$ - $\quad$ APPLICATION OF BACTERIA ONLY

$\mathrm{C} \quad$ - $\quad$ APPLICATION OF FERTILIZER ONLY

D $\quad-\quad$ NO APPLICATION

E $\quad-\quad$ ADDITION OF BIOCIDE 
Fig.2 Growth profile of HUB in sludge polluted brackish water sample during the monitoring of the various bioremediation options

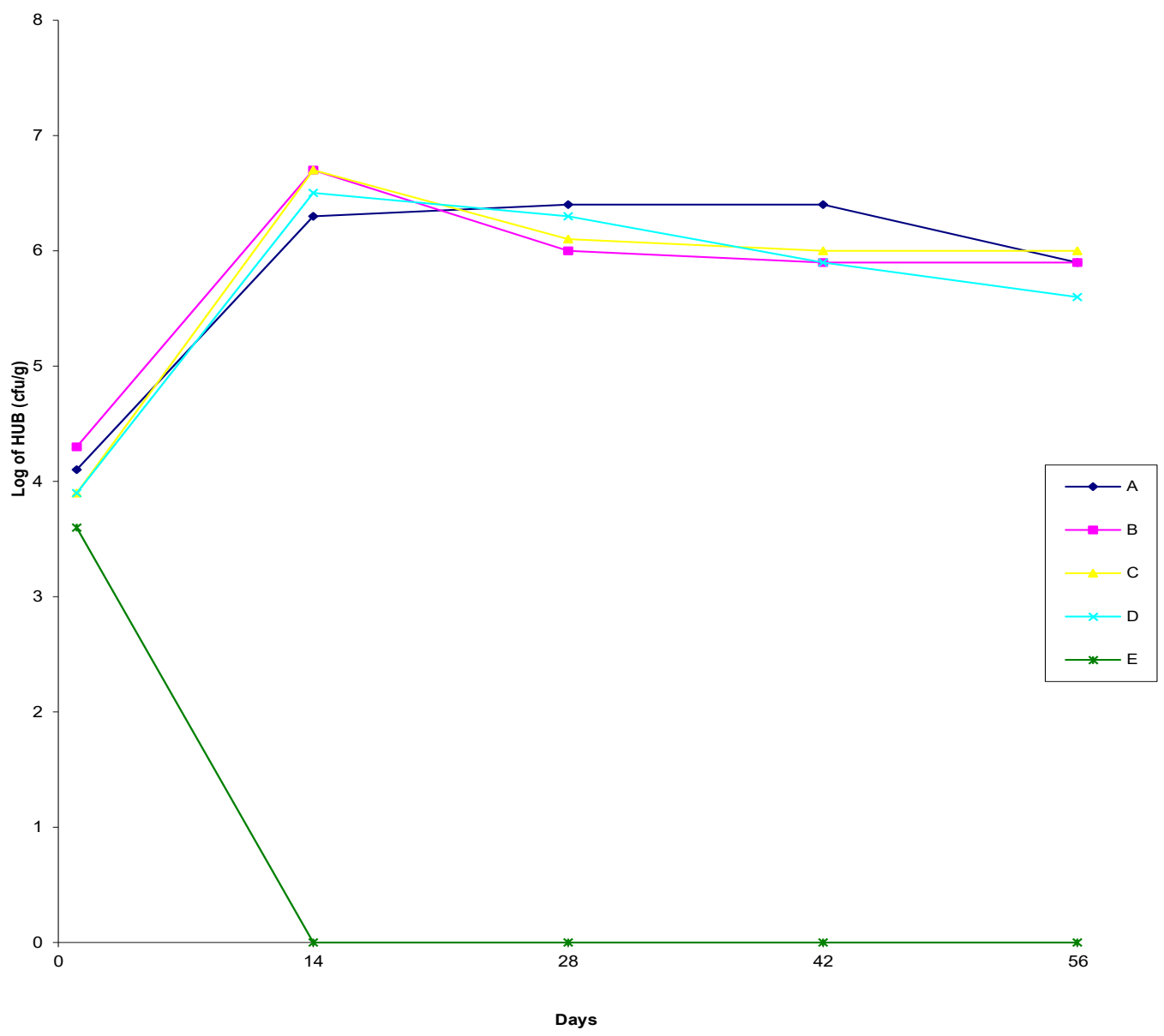

$\begin{array}{lll}\text { KEY } & & \\ \mathrm{A} & - & \text { APPLICATION OF BACTERIA AND FERTILIZER } \\ \mathrm{B} & - & \text { APPLICATION OF BACTERIA ONLY } \\ \mathrm{C} & - & \text { APPLICATION OF FERTILIZER ONLY } \\ \mathrm{D} & - & \text { NO APPLICATION } \\ \mathrm{E} & - & \text { ADDITION OF BIOCIDE }\end{array}$


Fig.3 Changes in $\mathrm{pH}$ level in sludge polluted brackish water sample during the monitoring of the various bioremediation options

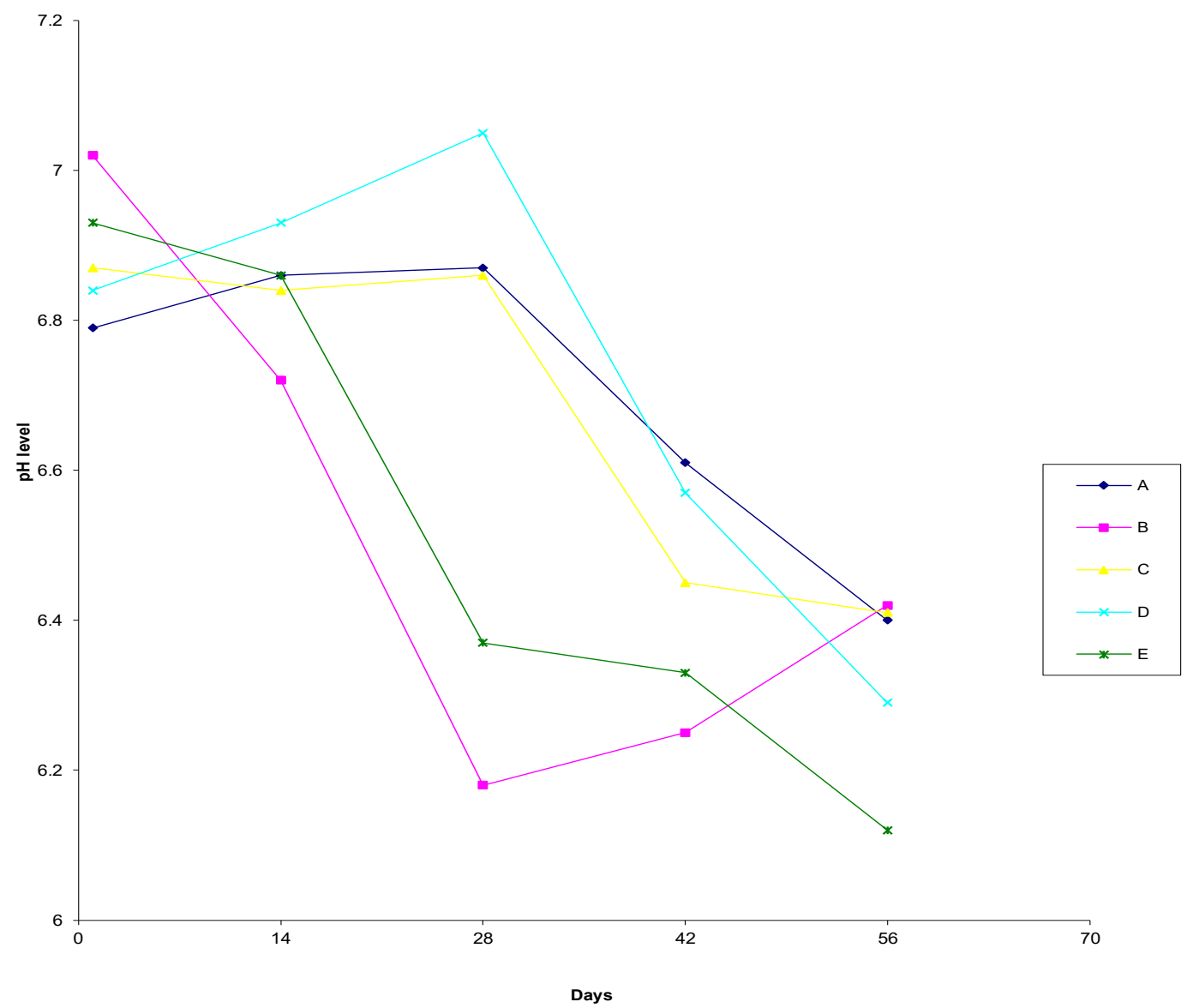

KEY

A $\quad-\quad$ APPLICATION OF BACTERIA AND FERTILIZER

$\mathrm{B} \quad$ - $\quad$ APPLICATION OF BACTERIA ONLY

$\mathrm{C} \quad$ - $\quad$ APPLICATION OF FERTILIZER ONLY

D $\quad-\quad$ NO APPLICATION

E $\quad-\quad$ ADDITION OF BIOCIDE 
Fig.4 Changes in salinity level in sludge polluted brackish water sample during monitoring of the various bioremediation options
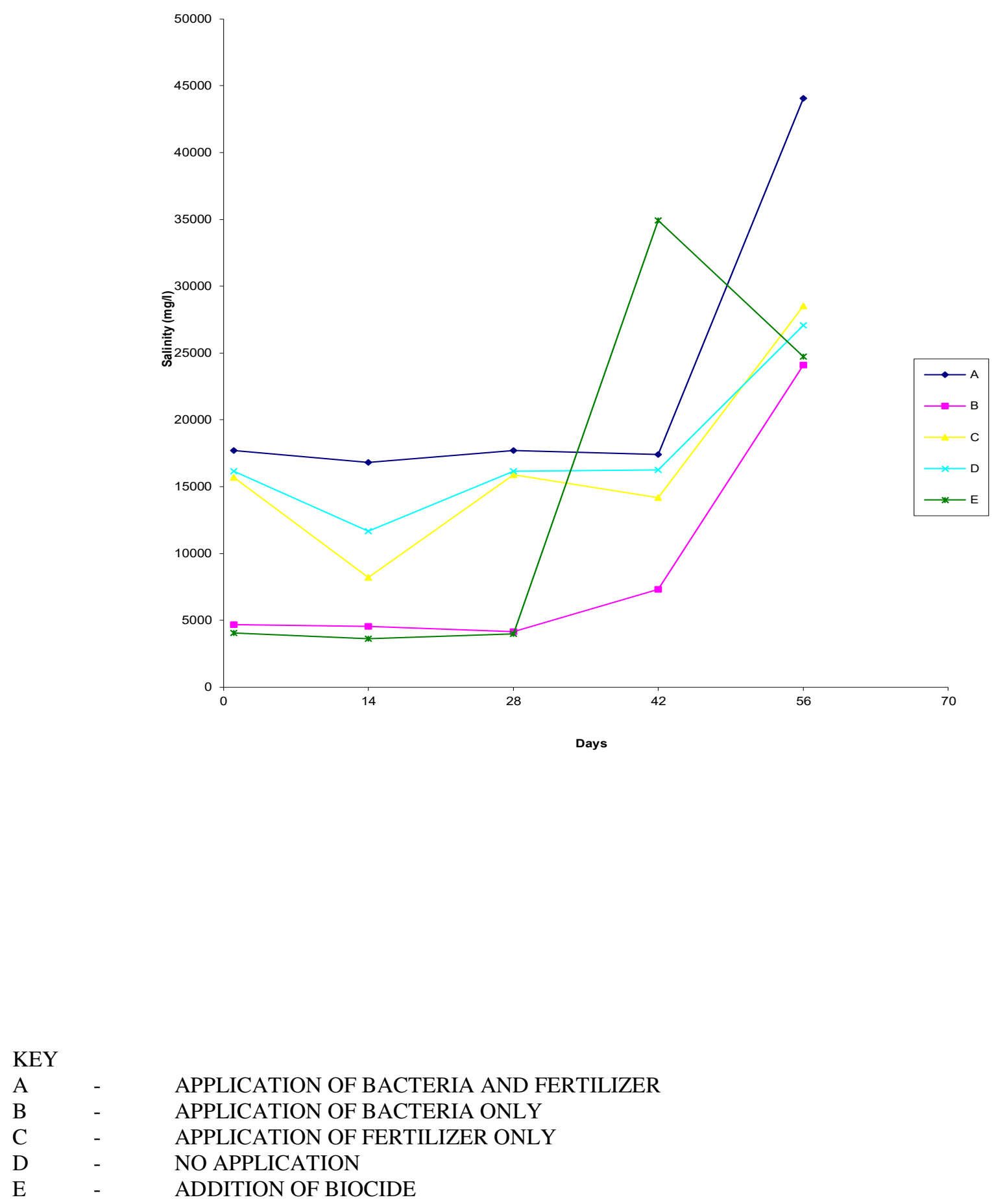
Fig.5 Changes in alkalinity level in sludge polluted brackish water sample during monitoring of the various bioremediation options
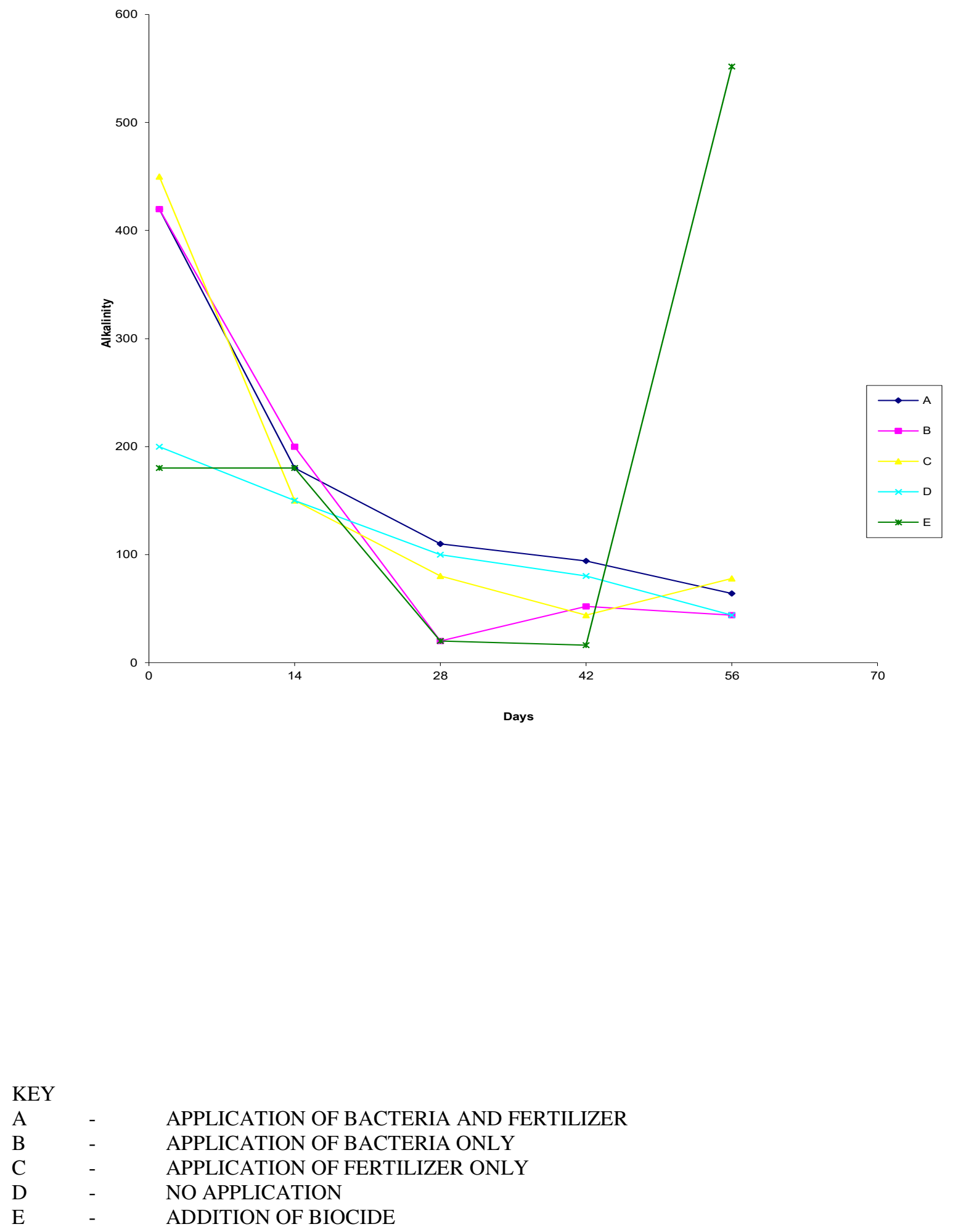
Fig.6 Changes in conductivity level in sludge polluted brackish water sample during monitoring of various bioremediation options

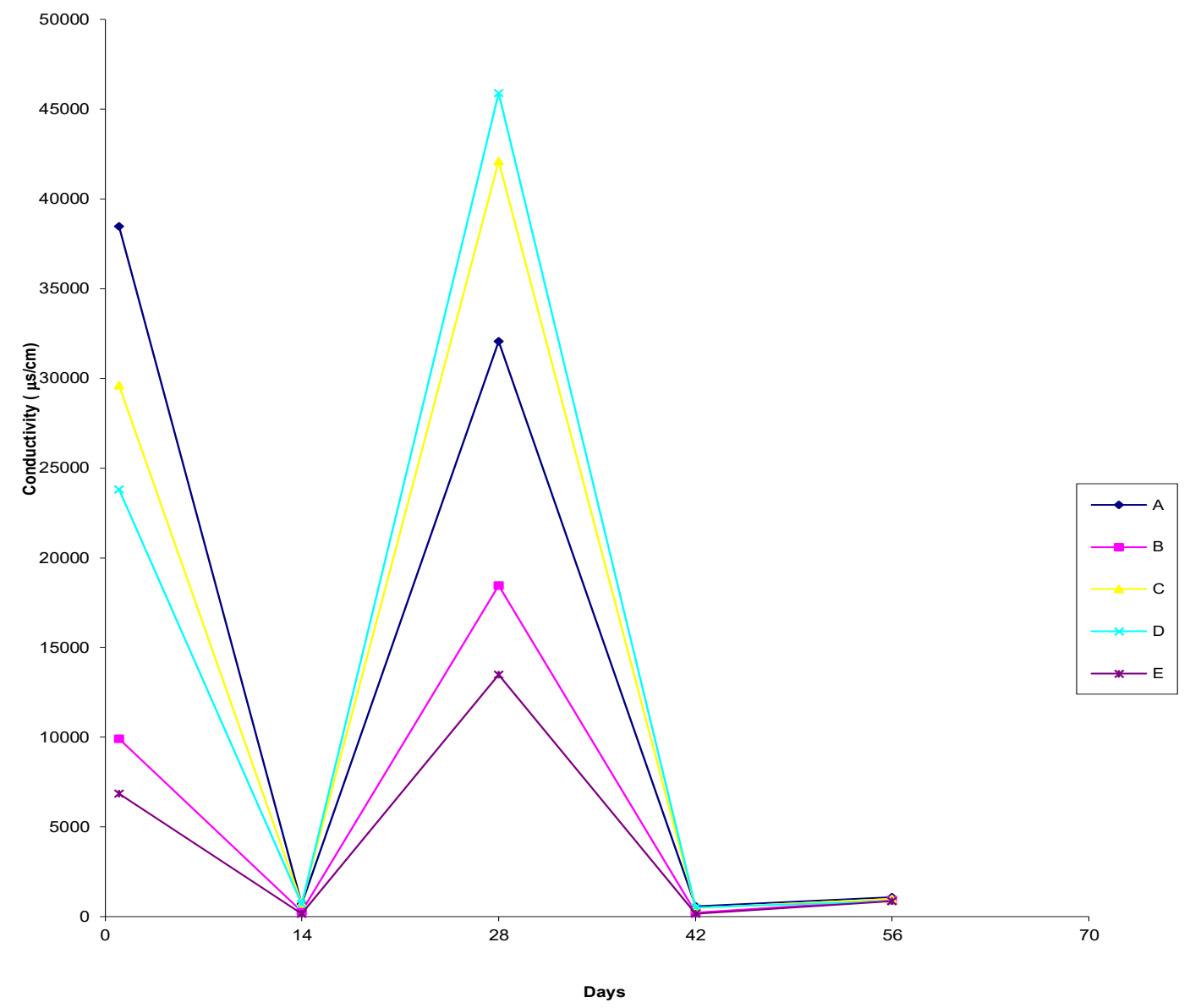

KEY

A - $\quad$ APPLICATION OF BACTERIA AND FERTILIZER

$\mathrm{B}$ - $\quad$ APPLICATION OF BACTERIA ONLY

$\mathrm{C} \quad$ - $\quad$ APPLICATION OF FERTILIZER ONLY

D - - NO APPLICATION

E $\quad-\quad$ ADDITION OF BIOCIDE 
Fig.7 Changes in BOD level in sludge polluted brackish water sample during monitoring of the various bioremediation options

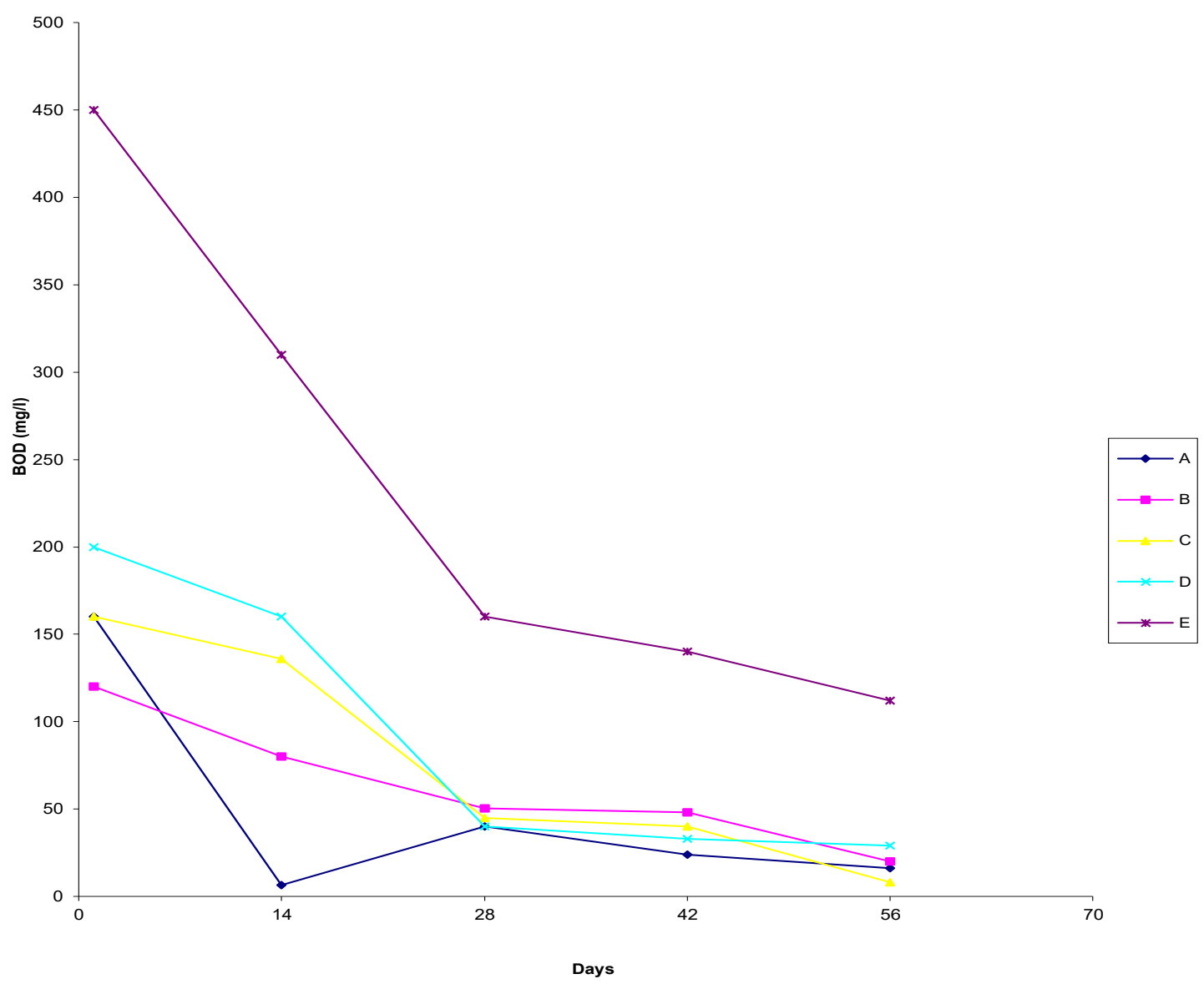

KEY

$\mathrm{A} \quad-\quad$ APPLICATION OF BACTERIA AND FERTILIZER

$\mathrm{B} \quad$ - $\quad$ APPLICATION OF BACTERIA ONLY

$\mathrm{C} \quad$ - $\quad$ APPLICATION OF FERTILIZER ONLY

$\mathrm{D} \quad$ - $\quad$ NO APPLICATION

E $\quad-\quad$ ADDITION OF BIOCIDE 
Fig.8 Changes in COD level in sludge polluted brackish water sample during monitoring of the various bioremediation options

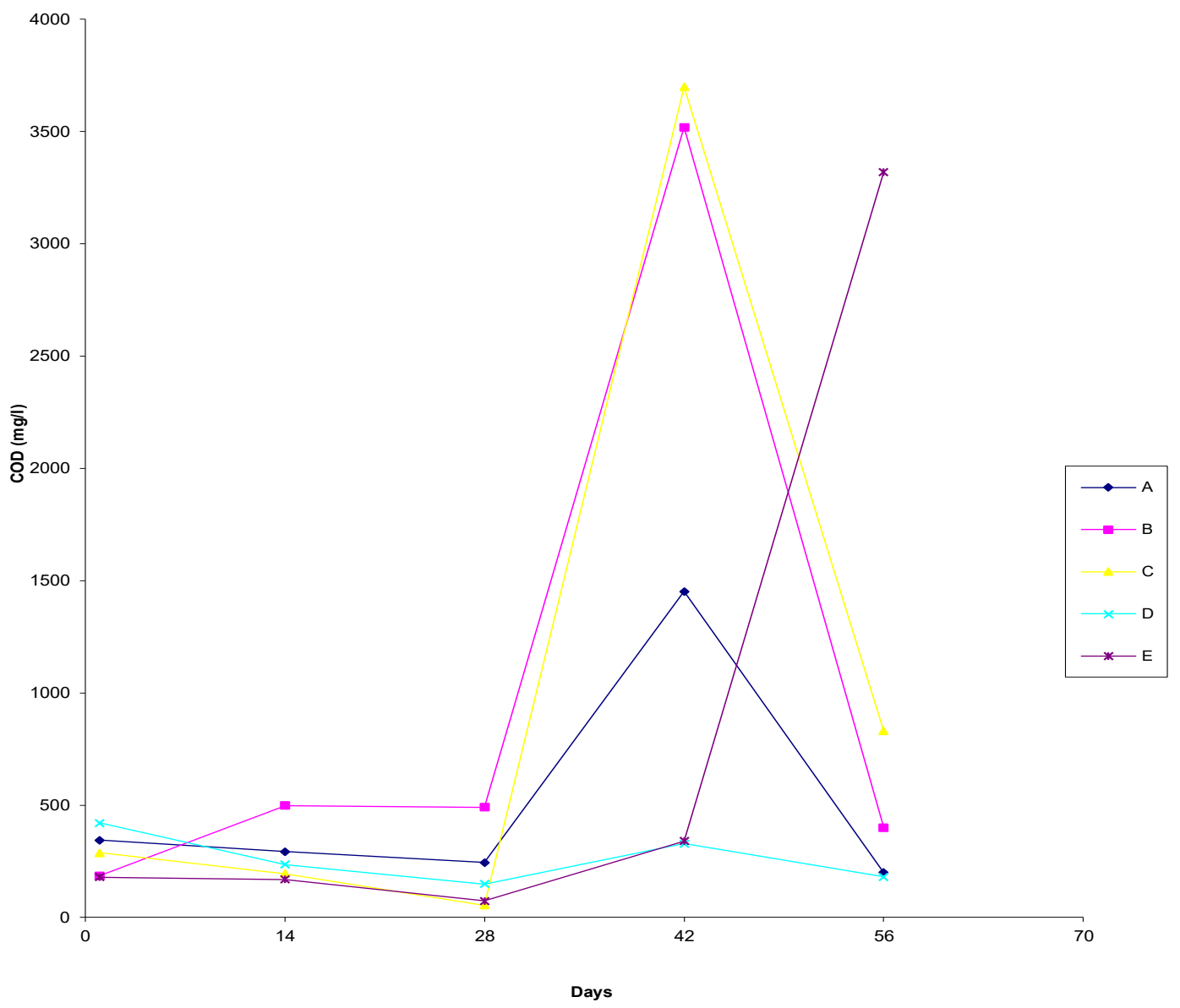

KEY

A $\quad-\quad$ APPLICATION OF BACTERIA AND FERTILIZER

$\mathrm{B} \quad$ - $\quad$ APPLICATION OF BACTERIA ONLY

$\mathrm{C} \quad$ - $\quad$ APPLICATION OF FERTILIZER ONLY

D $\quad-\quad$ NO APPLICATION

E $\quad-\quad$ ADDITION OF BIOCIDE 
Fig.9 Changes in nitrate level in sludge polluted brackish water sample during monitoring of various bioremediation options

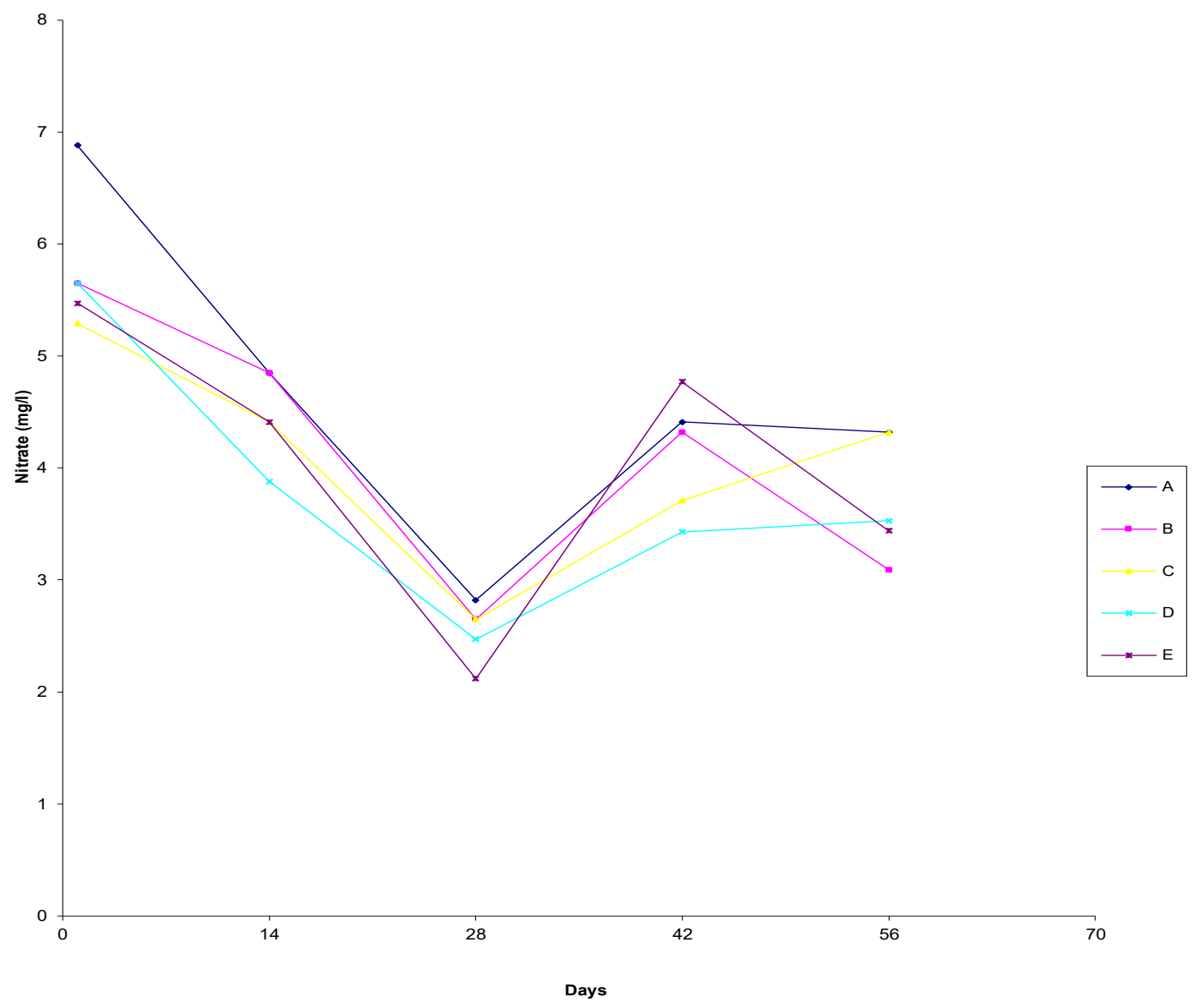

KEY

A - $\quad$ APPLICATION OF BACTERIA AND FERTILIZER

$\mathrm{B}$ - $\quad$ APPLICATION OF BACTERIA ONLY

$\mathrm{C} \quad$ - $\quad$ APPLICATION OF FERTILIZER ONLY

D - - NO APPLICATION

E $\quad-\quad$ ADDITION OF BIOCIDE 
Fig.10 Changes in phosphate level in sludge polluted brackish water sample during monitoring of the various bioremediation options

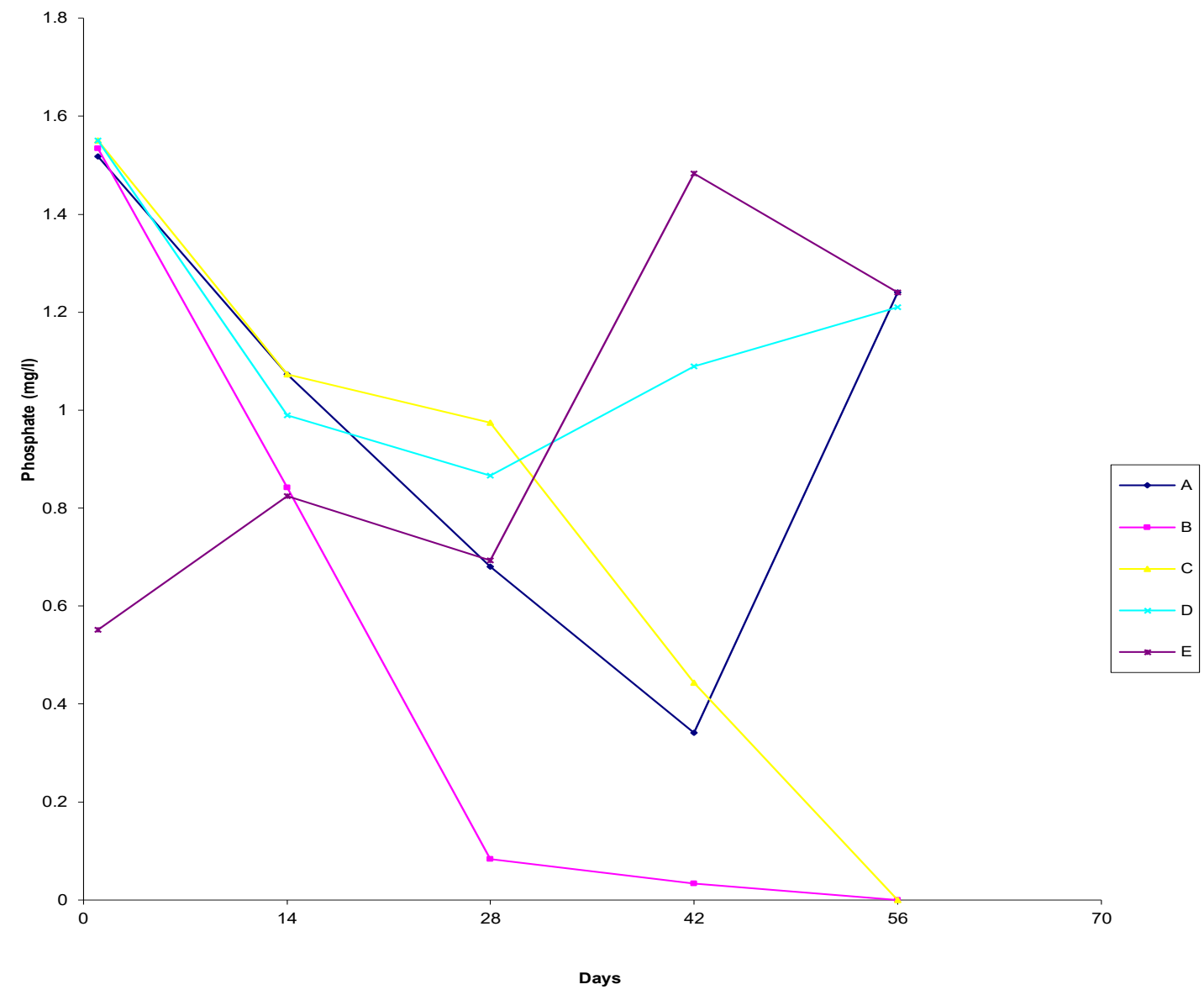

$\begin{array}{lll}\text { KEY } & & \\ \mathrm{A} & - & \text { APPLICATION OF BACTERIA AND FERTILIZER } \\ \mathrm{B} & - & \text { APPLICATION OF BACTERIA ONLY } \\ \mathrm{C} & - & \text { APPLICATION OF FERTILIZER ONLY } \\ \mathrm{D} & - & \text { NO APPLICATION } \\ \mathrm{E} & - & \text { ADDITION OF BIOCIDE }\end{array}$


Fig.11 Changes in sulphate level in sludge polluted brackish water sample during monitoring of the various bioremediation options

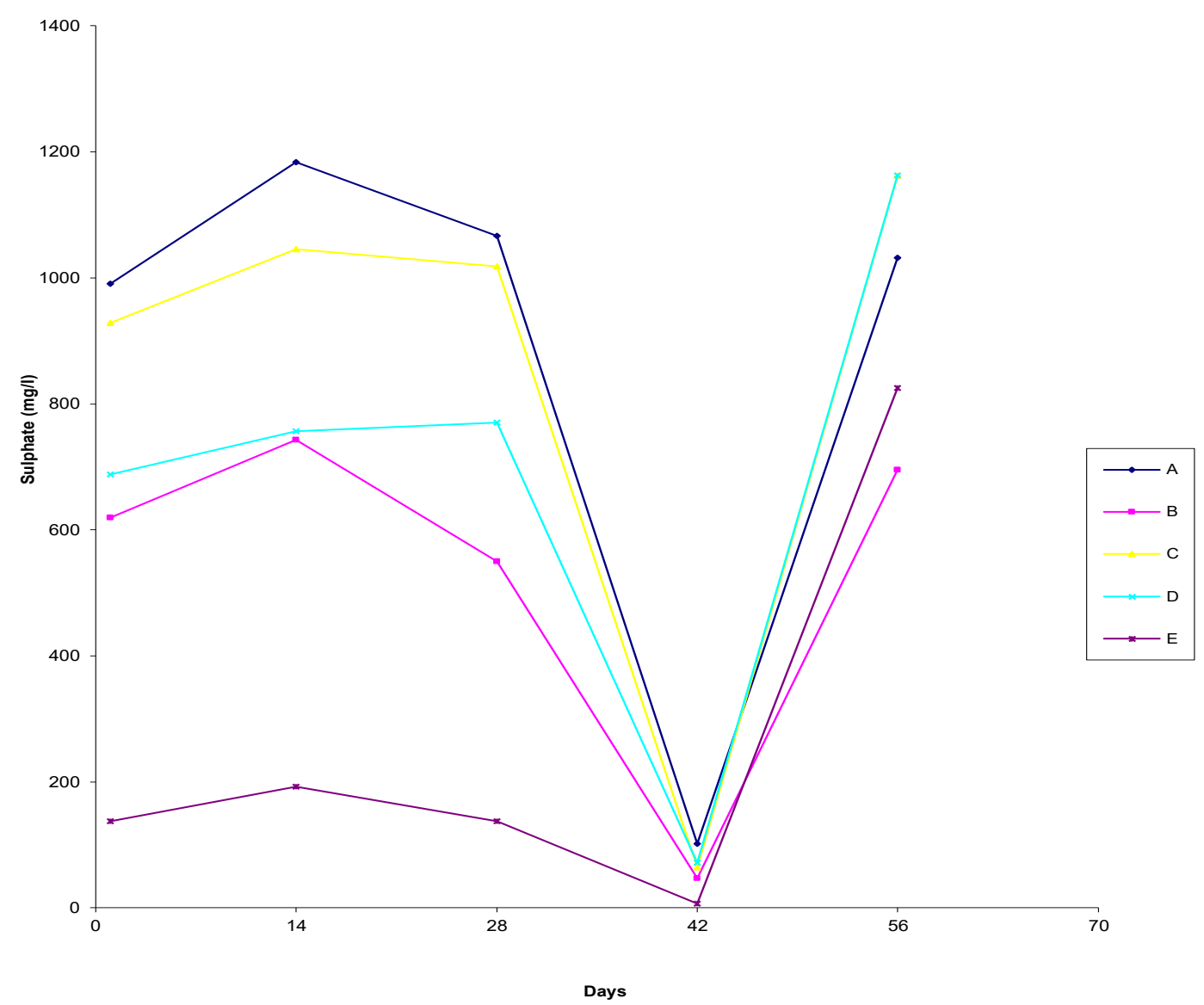

$\begin{array}{lll}\text { KEY } & & \\ \mathrm{A} & - & \text { APPLICATION OF BACTERIA AND FERTILIZER } \\ \mathrm{B} & - & \text { APPLICATION OF BACTERIA ONLY } \\ \mathrm{C} & - & \text { APPLICATION OF FERTILIZER ONLY } \\ \mathrm{D} & - & \text { NO APPLICATION } \\ \mathrm{E} & - & \text { ADDITION OF BIOCIDE }\end{array}$


Fig.12 Changes in THC level in sludge polluted brackish water sample during monitoring of various bioremediation options

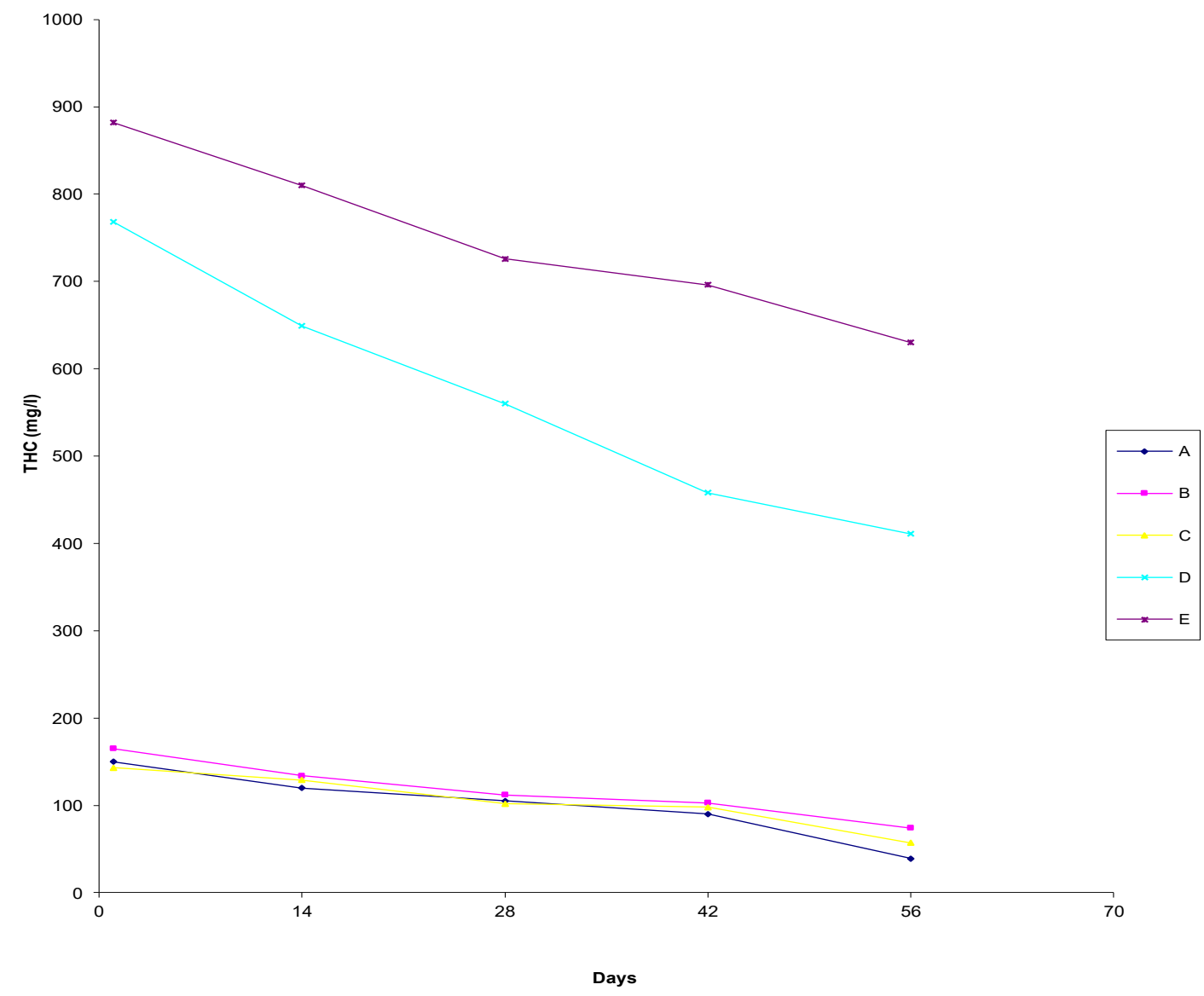

KEY

A $\quad-\quad$ APPLICATION OF BACTERIA AND FERTILIZER

$\mathrm{B} \quad-\quad$ APPLICATION OF BACTERIA ONLY

$\mathrm{C} \quad-\quad$ APPLICATION OF FERTILIZER ONLY

D $\quad-\quad$ NO APPLICATION

E $\quad-\quad$ ADDITION OF BIOCIDE 
Fig.13 Agarose gel electrophoresis results of the $16 \mathrm{~S}$ gene bands of the isolates: L: represents the $1 \mathrm{~kb}$ ladder, $\mathrm{N}$ : represents the negative control, 1-8 represents $16 \mathrm{~S}$ gene bands of the isolates

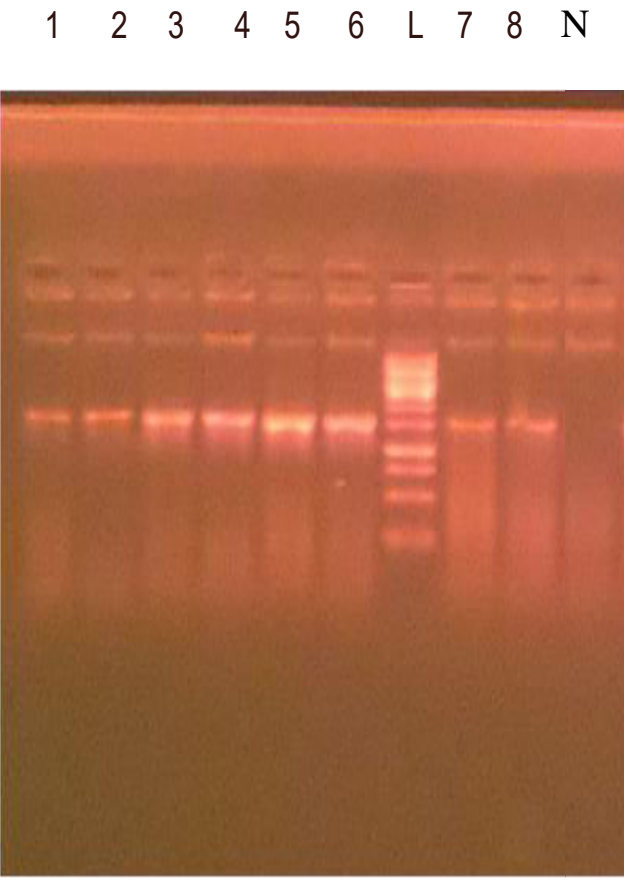

Generally, changes in COD, nitrate, phosphate and sulphate showed different trend of reduction or increase during the remediation period in the different treatment options (Figs. 8-11). The relative reductions in nitrate, sulphate and phosphate levels in the treatment options indicate that the HUB degraders were actively utilizing the metallic salts of the anions as sources of nitrogen and sulphur (Odokuma and Akpokodje, 2004; Odokuma and Okara, 2005).

There were reductions in the values of THC from day 0 to day 56 in all the treatment options. There was slight reduction in THC in the control option $\mathrm{E}$ which is attributable to natural attenuation (Vidali, 2001). The reductions in the test options indicates that hydrocarbon degraders were utilizing the hydrocarbon in the pollutants as sources of carbon and energy for metalbolic activities thereby reducing the content (Ayotamuno et al., 2011; Malik and Ahmed, 2012; Mona et al., 2015; Macaulay, 2015).
The results of $\%$ losses in TPH showed that treatment options $\mathrm{C}$ had the highest $(95.1 \%)$ followed by option B (92.51\%), option A (91.8\%) and D (57.8\%) respectively. This implies that biostimulation (additions of NPK fertilizer) could have stimulated and enhanced degradation rate by providing the limiting nutrients in the system required for cell growth such as nitrogen and phosphorus (Nester et al., 2001).

The result of \% TPH loss in treatment option D (57. 8\%) which was more than in the control option $\mathrm{E}(39.5 \%)$ and less than in actual treatment options (A, B and C) suggests that microorganisms (HUB) played important role in the degradation process of the hydrocarbon pollutants in the aquatic system, since there was no nutrient supplement (biostimulation) and no addition of indigenous HUB (bioaugmentation). The differences in the \% losses of TPH in the treatment options could be attributed to various factors, the microbial population of 
the aquatic environment (Phulia et al., 2013), the physicochemical characteristics of the aquatic system, available nutrients, chemical composition and physical nature of the pollutant (petroleum sludge) and bioremediation technology employed. The results suggest that biostimulation with NPK fertilizer will enhance bioremediation of petroleum oily sludge polluted aquatic system more than bioagumentation and a combination of the two. These observations from this study are in general agreement with various studies and reports regarding the use of biostimulation/bioaugmentation in clean-up of hydrocarbon polluted environments (Vidali, 2001; Odokuma and Dickson, 2003; Mukred et al., 2008; Ayotamuno et al., 2007; Ayotamuno et al., 2011; Mona et al., 2015; Macualey, 2015; Crisafi, et al., 2016; Wokem and Odokuma, 2016).

The agarose gel electrophoreses results of the $16 \mathrm{~S}$ gene bands of the isolates are shown in Fig. 13. The bacterial sequences submitted to GenBank were assigned Accession Number KX8172218-KX817225 (Table 9). From the molecular identification of the isolates the following organisms were implicated in the overall hydrocarbon degradation namely; Klebsiella pneumoniae B21, Klebsiella pneumoniae ICB-C183, Klebsiella oxytoca BCNAI, Klebsiellaoxytoca BC4, Alkaligenes faecalis IOU PMR, Alacligenesfaecalis AQ-1, Klebsiella pneumoniae ICB-C26 and Klebsiella pneumoniae B21F4 Table 9. Alkaligenes faecalis has been explored for use to promote biodegradation of petroleum hydrocarbons A. faecalis produces biosurfactants which possessed high surface activity, decreasing surface tension adequately to allow for degradation of hydrocarbon (Igwo-Ezikpwe et al., 2009). Species identified in this study have also been implicatedin crude oil degradation in other studies (Rodrigues et al., 2009; Chamkha et al., 2011; Olukunle, 2013; Chikere and
Ekwuabu, 2014).

In conclusion, the findings in the present study indicate that petroleum oily sludge possess serious potential environmental hazard as a result of the high TPH and PAHs which are known to be major contaminants. The results of bioremediation of petroleum sludge polluted brackish aquatic system investigated in this study, suggests that the use of biostimulation with NPK fertilizer, the use of bioaugmentation with indigenous HUB or the combination of the two techniques will enhance and be effective in the bioremediation of petroleum sludge polluted aquatic system.

\section{References}

Ahirwar, S and Dehariya, R (2013). Isolation and characterization of hydrocarbon degrading microorganisms from petroleum oil contaminated soil sites. Bull. Environ. Sci.

Amanchukwu, S. C., Okpokwasili, G. C. and Obafemi, A (1989). Factors affecting hydrocarbon degradation by Schizosaccharomycespombe isolated from palm wine. Proceedings of 1987 Seminar on the petroleum Industry and the Nigerian Environment. pp. 154-160. Department of Petroleum Resources (DPR) and Nigerian National Petroleum Corporation (NNPC), Lagos, Nigeria.

American Public Health Association- APHA (1998). Standard Methods for examination of water and waste water $20^{\text {th }}$ ed. Washington DC: American works Association, water pollution control federation.

American Society for Testing Materials ASTM D7678 (1999). Standard Test Method for total petroleum hydrocarbon in water and wastewater with solvent Extraction using Mid-IR laser Spectroscopy. 
American Society for Testing Materials ASTM D8270 (1999). Standard Test Method for total petroleum hydrocarbon-volatile organic compounds by Gas Chromatography.

Atlas, R. M. (1984). Microbial degradation of petroleum hydrocarbons: An environmental perspective. Microbial Rev. 54:180-209.

Ayotamuno, M. J., Okparanma, R. N. and Amadi, F. (2011).Enhanced remediation of an oily sludge with saline water.Afri. J. Environ. Sci. Tech. 5 (4): 262-267.

Ayotamuno, M. J., Okparanma, R. N., Ogaji, S. O. T and Robert, S.D (2007) Bioremediation of a Sludge Containing hydrocarbon. J. Appl. Energy 84 (9): 936-943.

Balachandran, C., Durapandiyan, V., Balakrisina, $\mathrm{K}$ and Ignacimuthu, $\mathrm{S}$ (2012). Petroleum and polycyclic aromatic hydrocarbons (PAHs) degradation and raphthalene metabolism in Streptomyces sp. (ERICPDA-1) isolated from oil contaminated soil. Bioresour. technol. 11: 83-90.

Bhahacharyya, J. K and Shekdar, A. V (2003).Treatment and disposal of refinery sludge; Indian Scenario.Waste Mgt. Res. 21 (3): 249-261.

Bundy, J. G., Paton, G. I., Campbell, C. D (2004).Combined microbial community level and single species biosensor responses to monitor recovery of oil pollutant soil.Biol. Biochem. 36 (7) 1149-11659.

Calfee, R. D., Little, E. E., Clevel, L and Barron, M. G (1999). Photo enhanced toxicity of a weathered oil to ceriodaphinadubia reproduction. Environ. Sci. Pollut. Resour. 6: $217-$ 212.

Cébron, A., Norini, M.P., Beguiristain, T and Leyval C. (2008). Real-time PCR quantification of PHA- ring hydroxylatingdioxygenase

(PAHRHDa) genes from gram positive and gram negative bacteria in soil and sediment samples J. Microbiol.Methods. 73:148-159.

Chamkha, M., Trabelsi, Y., Mnif.S and Sayadi. S (2011) Isolation and characterization of Klebsiellaoxytoca strain degrading crude oil from Tunisian off-shore fields. J. Basic Microbiol. 5(6): 580-589.

Cheesbrough, M. (2006). District Laboratory Practice in Tropical countries, part 2, London, Cambridge University Press. Pp 58-100.

Chikere, C. B and Ekwwuabu, C. B. (2014). Culture dependent characterization of hydrocarbon utilizing bacteria in selected oil impacted sites-in Bodo, Ogoniland, Nigeria. Afri. J. Environ. Sci. Technol. 8 (6): 401-406.

Chikere, C. B., Okpokwasili, G. C and Chikere B. O. (2009). Bacterial diversity in a tropical crude oil polluted soil undergoing bioremediation. Afri. J. Biotechnol. 8: 2535-2540.

Crisafi, F. Genovase, M., Smedite, F., Russso, D., Cataliforna, $\mathrm{M}$ and Yokimov, $\mathrm{M}$ (2016). Bioremediation techniques for polluted sea-water sampled after an oilspill in Taranto gulf (Italy): A comparison of biostimulation, bioaugmentation and use of a washing agent in microsom studies. Marine Pollution Bulletin.106 (1-2): 119.

Dean-Ross, D. Moody, J., Cemigla, C.E (2002). Utilization of mixtures of polycyclic aromatic hydrocarbons by bacteria isolated from contaminated sediment. FEMS. Microb. Ecol. 4 (1): 1-7.

Delyan, U. H., Harder, M. and Hopner, T. H (1990).Hydrocarbon biodegradation in sediments and soils.Systematic examination of physical and chemical conditions part II $\mathrm{pH}$ values. 
WissechaftTechnik Sci. Technol. 43: 337-342.

Department of Petroleum Resources- DPR (2002). Environmental Guideline and Standards for Petroleum Industry in Nigeria. (EGASPIN). Revised edition, Department of Petroleum Resources, Abuja, Nigeria P: 314.

Felsentein, J. (1985). Confidence limits on phylogenies: An approach using bootstrap. Evolution. 39: 783-791.

Hara, E., Kurihara, M., Mormura, N., Nakajira, T and Uchiyama, H (2013). Bioremediation field trial of oil contaminated soil with food waste compost. J. JSCE: 1 (1): 125-132.

Holt, J. G., Krieg, N. R., Sneath, P. H. A., Staley, J. T. and Williams, S. T. (1994). Bergey's Manual of Determinative Bacteriology, $\left(9^{\text {th }}\right.$ ed). Williams and Wilkins Co., Baltimore.

Igwo-Ezikpe, M.N., Gbenle, O.G., Ilori, M.O., Okpuzor, J., and Osuntoki, A. A (2009) Evaluation of Alcaligenesfaecalis degradation of chysene and diesel oil with concomitant production of biosurfactant. Res. J. Environ. Toxicol.3:158-169.

Krebs, G. T and Tanner, G. E (1986).Restoration of oiled marshes through sediment stripping and spartina propagation. Proceedings of the 1981 oil spill conference, American Petroleum Institute API, Washington DC, 315-385.

Macaulay, B. M (2015).Understanding the behavior of oil-degrading microorganisms to enhance the microbial remediation of spilled petroleum. Appld. Ecol. Environ. Resour, 13 (1): 247-262.

Malik, Z. A and Ahmed, S (2012). Degradation of petroleum hydrocarbon by oil field isolated bacterial consortium. Afri. J. Biotechnol., 11 (3): $650-658$
Manning, F. C. and Thompson, R. E (1995).Oil filed processing crude oil, Tulsa Pennwell books 2:5.

Mayo, A. W and Noike, T (1996).Effects of temperature and $\mathrm{pH}$ on growth of heterotrophic and bacteria in waste stabilization ponds. Water Research 30 (2): 447-455.

Milic, J., Beskoski, V., Ilic, M., Ali, S., Gojgic-Cvijovic, $\mathrm{G}$ and Vrvic, $\mathrm{M}$ (2009). Bioremediation of soil heavily contaminated with crude oil and its products: composition of the microbial consortium. J. Serb. Chem. Soc. 74 (4): $455-460$.

Mills, A. C., Breuil, C. and Cowell, R. R. (1978).Enumeration of Petroleum degrading marine and estuarine microorganism by the Most Probable Number (MPN) method. Canad. J. Microbiol., 25: 552-557.

Milne, B (1998). Composting of heavy oil Refinery sludge. Environ. Programme 17 (1): $17-24$.

Mona, S. Z., Mohammed, M. N. A and Hossam, H. H.A (2015).Bioremediation of petroleum contaminants in aquatic environments. Life Sci. J., 12 (5): 127139.

Mukred, A. M., Hamid, A. A., Hamzah, A and Yusoff, W. M. W (2008).Development of three bacteria consortium for the Bioremediation of crude petroleum-oil in contaminated water.Online J. Biol. Scis. 8 (4): 16084217.

Nester, E.W., Anderson, D.G., Roberts, C.E., Pearsall, N.C and Nester, M.T (2001).Microbiology: A human perspective. $4^{\text {th }}$ ed. McGraw. Hill Co. Inc, New York. Pp 781-793.

Obire, O and Akinde, S. B (2004). Poultry manure amendment of oil polluted soils for sustainable development in the Niger Delta J. Nig. Environ. Soc. 2 (2): $138-143$. 
Odokuma, L. O and Akpokodje, E. G (2004).Biodegradation of stimulated landfill leachate in tropical soil of depth 6.5 metres. J. Appld. Sci. Technol. 4 (1): 6-14.

Odokuma, L. O and Dickson, A. A. (2003). Bioremediation of crude oil polluted tropical mangrove environment. $J$. Appld. Sci. Environ. 7 (2): 23-29.

Odokuma, L. O and Okara, J. O (2005). Biodegradability of grounded cell phone recharge cards in two Niger Delta soils. J. Appld. Sci. Technol. 5 (1-2): 11-20.

Odokuma, L. O and Okporwasili G.C (1993a). Seasonal ecology of hydrocarbon-utilizing microbes in the surface waters of a river. Environ. Monit. Assess. 27:175-191.

Odokuma, L. O and Okporwasili G.C (1993b). Seasonal influences on inorganic Anion monitoring of the new Calabar River Nigeria. Environ. Mgt 17 (4): 491-490.

Odokuma, L. O. and Okporwasili G. C. (1997).Seasonal influence of organic pollution monitoring of the New Calabar River, Nigeria. Environ. Monit. Assess. 45: 43-56.

Odokuma, L. O. and Smith, V. A (2007).Bioremediation of a Nigerian crude oil by chrococcus and chlorella species.Trop. Freshwater Biol., 16 (1): 17-30.

Odokuma, L. O., and Ibor, M. N (2003). Bioremediation of crude oil polluted tropical soil by nutrient supplementation. Sci. Afri. 1(2):1-5.

Odokuma, L.O and Ibe, C. O (2003).Bioremediation of paper and polyethylene using immobilized and free bacterial cells.Nig. J. Microbiol., 17 (1): 17-25.

Okpowasili, G. C. Odokuma, and L. C. (1990). Effects of salinity on biodegradation of oil spill dispersants Waste Mgt. 10: 141-146.
Phulia, V., Jamwal, A., Saxena, N., Chadha, N. K., Muralidhar, A. P and Prusty, A. K. (2013).Technologies in aquatic bioremediation. Pp 65-91. In: Kumar, P., Zaki, M.S.A and Chauhan A. (Eds.), Freshwater Ecosystem and Xenobiotics. Discovering Publishing House PVT. Ltd., New Delhi, India.

Riser-Roberts, E (1992). Bioremediation of petroleum contaminated sites $\mathrm{CK}$ Smoley, Boca Raton.

Rodrigues, D. F., Sakate, S. K., Comassento, J. V., Bic, M. C and Pellizanri V. A. (2009). Diversity of hydrocarbondegrading klebsiella strains isolated from hydrocarbon contaminated estuaries. J. Appl. Microbiol. 106 (2): 1304-1304.

Saituo, N and Nei, M (1987). The neighbor joining method: A new method for reconstructing phylogenetic trees. Mole. Biol. Evol., 4:406-425.

Singh, K and Chandia S (2014). Treatment of petroleum hydrocarbon polluted environment through bioremediation: a review. Pak. J, Biol. Sci. 17 (1) 1-8.

Stewart, E. A., Maxcrimshaw, H., Parkinson, J. A and Quarmby, C. (1974).Chemical Analysis of Biological Materials.Blackwell Scientific Publication.Oxford London.

Thompson, J. D., Gibson, T. J., Plewniak, F., Janmeugin, F and Higgins, D. G (1994). The cluster IX windows interface flexible strategies for multiple sequence alignment aided by quantity analysis tools. Nucleic Acid Resour. 22:46734680.

Tyagi, M., Yafonseca, M. and Carvalho, C. (2011).Bioaugmnetation and Biostimulation strategies to improve the effectiveness of bioremediation process, Biodegra, 22.

Vidali. M. (2001). Bioremediation an Overview. Pure Appld. Chem., 73 (7) 116-1172. 
Vijayadeep, C. and Sastry, P. S. (2014).Effect of heavy metal uptake by $E$. coli and Bacillussps. J. Biorem. Biodegra.5: 238.

Wang, X. B., Chi, C. Q., Nie., Y., Tang, Y. Q., Tan, Y., Wu., G and Wu., X. L (2011). Degradation of petroleum (C6C40) and crude oil by a novel Dietzia strain Bioresour. Technol. 102 (7): 7755-7761.

Wokem, V. C and Odokuma L. O (2016). Bioremediation of condensate polluted freshwater Ecosystem. Nat. Sci. 14 (7): 96-102.

Wu, Y., Luo, Y., Zuo, D., Ni, J., Liu, W., Teng, $\mathrm{Y}$ and Li, Z (2008). Bioremediation of polycyclic aromatic hydrocarbons contaminated soil with Monilinia sp. Degradation and microbial community analysis. Biodegra. 19 (2): 247-257.

\section{How to cite this article:}

Vincent C. Wokem, Lucky O. Odokuma and Caroline N. Ariole. 2019. Bioremediation of Petroleum Oil Sludge Polluted Brackish Water Ecosystem. Int.J.Curr.Microbiol.App.Sci. 8(09): 2819- 2846. doi: https://doi.org/10.20546/ijcmas.2019.809.325 